性を議論した研究, ポリプロピレンを変性して, 流動性と 物性との両立を目指した材料の研究発表が行われた。会場 は，80名程度が入れる規模であったが，立ち見が出るほ ど多くの人が来場して聴講していた．スクリーンが小さく， 後乃の方からやや見難い点はあったが，質疑が非常に活発 に行われ活気のある雲囲気の会場であった．私の個人的感 想であるが, どの講演も研究テーマの着眼点がユニークで, それに対するアプローチも充実しており，聞いていて面白
いと感じられる講演が多く非常に勉強になった。今回の 「材料の機能を引き出すプロセシング」という切り口は, 興味深い講演が集まり，良かったと思うが，他のセッショ ンと分野が関連するものが多く，他の会場に聴きたい講演 がパラレルで走っていて, 苦渋の選択を迫られることがし ばしばあった，今後，プログラム編成に工夫が必要かもし れない。

\title{
特別セッション II
}

\section{生分解性プラスチックの創製，成形，評価（E-101〜 E-106， E-201〜 E-209）}

開発の進展とともにその活用が期待される生分解性プラ スチックに関する研究が 15 件報告された。午前中のセッ ションにも係らず，多くの参加者があり，熱心に講演を聴 講していたのは印象的であった。

今回のセッションでは, 生分解性プラスチックの実用化 を図る上で障害となっている弾性率，耐熱性といった材料 特性を改善する目的の研究が多く占めていた。 そのうち添 加剤の検討を行った研究が 5 件, プラスチック同士のブレ ンドに関する研究が 2 件, 新たな生分解性プラスチックの 開発が 3 件，成形技術に関する研究が 3 件，リサイクル技 術と特性評価に関する研究がそれぞれ 1 件という割合で あった。

添加剤に関しては，アラミド繊維，ジュート，非晶性米 粉等が提案された。樹脂物性向上のために用いる添加剤の 種類および効果に関する研究の展開が期待される.

石油系現行樹脂である PP P ABS 材料と同等以上のポ

\footnotetext{
* Suzuki, Hiroshi

九州工業大学 情報工学部 機械情報工学科

飯塚市川津 680-4（宁820-8502）
}

リ乳酸が開発されたとの報告があり，注目を浴びていた。 射出成形用難燃ポリ乳酸やシート材向けのポリ乳酸が示 され，量産技術の確立とともに，低コスト化が実現できれ ば，利用範囲は大きく広がるものと期待される，材料の開 発には軟質化・ナノ結晶技術を応用したとあり，今後この 分野への進展に寄与するものと感じた.

PLLA に PCL をブレンドすることで脆性が改善された 研究では医療分野への展開可能となる. また結晶化 PLLA に脆性高分子をブレンドすることで延性的な性質を持たせ る可能性には今後の展開が期待される.

LL-ラクチドの回収に関しては，従来よりも収率や光 学純度が向上したことが示された。これによりケミカルリ サイクルへの課題解決につながると考えられる.

PLAの発泡成形ではこれまで多くの課題があったがSFC を活用することで新たな製品開発に役立つ可能性がある. PLA を生体吸収材料として鍛造加工する試みは，材料の 新たな特性を引き出すもので他分野への応用も期待できる. PVA と落花生款とのホットプレス複合加工では, 資源の 有効活用の面からも今後の展開が期待される.

\section{特別セッション III}

\section{エラストマーの基礎設計と応用技術 1 （C-101～C-106）}

河 原 成 元 $^{*}$

エラストマーの基礎設計と応用技術では，熱可塑性エラ ストマーの一次構造から高次構造を制御することによる高 性能化および高機能化に関する報告があった。ポリウレタ ンエラストマー，スチレンーイソプレンースチレントリブ ロック共重合体 (SIS), ポリプロピレンおよびポリエチレ ンアイオノマーといった熱可塑性エラストマーに関して, 構造と物性の関係から射出成形における高次構造の制御ま で，報告は多岐にわたっていた。

熱可塑性エラストマーは，ハードセグメントが結晶化ま たはガラス化することによって物理的架橋点を形成するた

\footnotetext{
* Kawahara, Seiichi

長岡技術科学大学 工学部 物質・材料系

長岡市上富岡町 1603-1（T940-2188）
}

め，ソフトセグメントのガラス転移温度および粘弾性のほ かに，ハードセグメントの転移温度等が分子設計および材 料設計において重要な因子となる.さらに，ポリウレタン 等の極性エラストマーは, ソフトセグメントとなるポリ オール，ハードセグメントとなるジイソシアナートおよび 鎖長延長剂から合成されるため，分子設計の幅は極めて広 く，構造と物性の関係に関しては不明な点が多い.

最初の 4 件の発表では, ポリウレタンエラストマーの架 橋や絡み合いの程度およびダングリング鎖の数とハードセ グメントの形成や物性との関係が報告された。グリシドー ルと環状酸無水物を用いた多分岐ポリエステルを合成して からポリオールと反応させることによる架橋密度, 結晶化 および物性の制御，ポリ（オキシプロピレン）トリオール 
と 2, 4-トリレンジイソシアネートの比を変えることに よる架橋点とダングリング鎖の数の変化と表面物性の関係 の解明, 絡み合いによる凝集構造と力学物性の関係の解明, ハードセグメントの凝集構造に及ぼす化学的架橋密度と硬 化温度の影響の解明が検討され, 新規解析法を駆使するこ とにより，ポリウレタンエラストマーという複雑系の物性 に影響を及ぼす因子が明確にされていた。

一方, 後半の 2 件の発表では, 射出成形におけるサンド イッチ構造体の成型や発泡成形においてガラス短繊維や造
核剤を用いる等の工夫を凝らし，高次構造を制御すること によって所望の物性の発現が検討された。エラストマーの 射出成形とういう応用技術が開発および改良され，実用化 に近付いていることが認められた。これらの報告は汎用の エラストマーであっても成形方法によって未知の物性を発 現させることが可能であることを示唆するものであり，エ ラストマーにおける成形加工技術の開発が重要であること を改めて実感した。

\section{特別セッション III}

\section{エラストマーの基礎設計と応用技術 2 （C-201～C-204）}

エラストマーの基礎設計と応用技術というキーワードの 中で，本セッションでは，熱可塑性エラストマーを用いた プラスチックの改質に関する研究 2 件と, それとは逆に, プラスチックによるエラストマー（天然ゴム）の改質に関 する計 4 件の報告があった．前者の研究では，プラスチッ クの海相にエラストマー (ゴム) 相がミクロ分散したポリ マーアロイの系であるのに対して, 後者では, エラストマー （天然ゴム）粒子がナノレベルの厚みのポリマー相で覆わ れたナノマトリックスが連続構造を形成した系であり，工 ラストマーの使われ方が対照的であった。

熱可塑性エラストマーによるプラスチックの改質におい て，対象としていたプラスチックはバイオマスプラスチッ クであるポリ乳酸（PLA）とエンジニアリングプラスチッ クであるポリカーボネート（PC）であり，それらを改質 するエラストマーとして共にスチレン系エラストマー (SEBS) が用いられていた. PLAの弱点である耐衝撃性・ 耐熱老化性を PC P SEBS とのアロイ化によって向上でき ることを明らかにしており，ガラス転移温度（Tg）が低 いエラストマー(島)相の負圧効果によるマトリックス (海) 相の延性化という概念が提唱された．溶融混錬後の冷却過 程では，Tgが高いプラスチック（海）相が先に固化する ため, Tgが低いエラストマー (島) 相は拘束下で収縮せ ざるを得ない，そのために，エラストマー相が負圧となり， 結果, 局所的な分子運動性が向上して延性効果が発現する といった機構である。この概念をもとに，Tg 近傍で長時 間熱処理すると脆くなる PC の耐衝撃性の向上に SEBS と のアロイが応用された。 その結果, $\mathrm{PC} / \mathrm{SEBS}$ アロイによ

\footnotetext{
* Yamasaki, Satoshi

三井化学(侏) 機能材料事業本部 開発センター 素材開発部 袖ヶ浦市長浦 580-32（テ299-0265）
}

り, physical aging が進行していても耐衝撃性が向上する ことが明らかになった。 physical agingが進行したPC/ SEBS アロイの高次構造の解明は今後の課題であるが, 多 軸押出機による混鍊により容易にアロイが調製できるため, 工業的な観点からも有益な成果と思われる。

もう一方の報告は，バイオプラスチック (エラストマー) の先駆けともいうべき天然ゴムの特徴を維持しながら，ポ リマーの機能を付与するために開発されたナノマトリック ス構造の相分離構造と力学物性に関する研究であった。そ の調製方法は, 脱タンパク質化された天然ゴムを水に分散 したラテックス状態でスチレンをグラフト重合した後，ラ テックスを凝固させる手法である。透過型電子線卜モグラ フィーや収束イオンビーム - 走査型電子顕微鏡を駆使して, ナノマトリックス構造の解析を進めており, 分子レベルで 相分離構造の議論が可能であった。ポリスチレン (PS) の 分子量や相構造の解析から，0.05〜 3 $\mu \mathrm{m}$ の不確定に分散 した天然ゴム粒子に数十 $\mathrm{nm}$ 厚みの PSが覆われており, そのPS は大よそ 1 分子であることが明らかにされた。天 然ゴム粒子内にも僅かながら PS は存在していたが，この ようなナノ相分離構造を形成することにより, 天然ゴム単 独と比較して，引張強度および貯蔵弾性率が各々 5 倍， 10 倍以上増加していた．弾性率が高いPS の単なる補強によ るものではなく, ナノマトリックスを形成しているがゆえ の効果であることも報告されており, 弾性率の向上以外に, 天然ゴムへの PS (ポリマー) 導入効果の解明が期待され る.

エラストマーを単なる一材料としてのみならず，他ポリ マーとのアロイ化あるいはナノ分散により，その応用技術 の進展が感じられたセッションであった。 